UDC 577.125.8:612.11/.16 (05)

D. A. Dorovsky, A. L. Zagayko

National University of Pharmacy

\title{
CRITICAL ROLE OF CHOLESTEROL TRANSFER PROTEIN IN ATHEROSCLEROSIS DEVELOPMENT
}

Cholesterol ester transfer protein (CETP) is a plasma protein that facilitates the transport of cholesterol esters and triglicerides between the lipoproteins. CETP collects triglycerides from very-low-density lipoproteins (VLDL) or low-density lipoproteins ( $L D L)$ and exchanges them for cholesterol esters from high-density lipoproteins (HDL). Mutations wich lead to the cholesterol ester transfer protein function reduction have been involved in atherosclerosis development. This mutations also increase the prevalence of coronary heart disease in patients with hypertriglyceridemia. There is a wide variety of HDL-C increase therapies that have been tested during the last ten years. Among them is the modification of cholesterol ester transfer protein function. A novel pharmacologic strategy was proposed where drugs are designed to modify the lipid substrate preference of cholesterol ester transfer protein instead of simply blocking its activity. This approach provides an opportunity to improve the lipid transfer properties of cholesterol ester transfer protein and to harness its capacity to alter lipid metabolism to achieve specific beneficial outcomes.

Key words: CETP; lipoproteins; atherosclerosis

Interaction of discoidal nascent HDL with CETP

The associations between the HDL metabolism, plasma level of HDL-cholesterol (HDL-C), and the atheroprotective functions of HDL have been the main forces to make HDL a potential therapeutic target $[9,14]$. Negative-stain electron microscopy (EM) experiments have demonstrated that CETP binds to the edge of nascent HDL since CETP curvature proved to match the edge of nascent HDL perfectly, while barely attaching at the narrow top side [6]. Cholesterol ester transfer protein also induced a change in the nascent HDL particle structure. The mechanism behind this interaction is the strong ionic interaction with POPC located at the surface of the discoidal high-density lipoprotein particles, as well as interactions with apoA-I. ApoA-I mobility at the discoidal HDL surface favors interaction with cholesterol ester transfer protein and the participation of apoA-I in CETP-HDL bounds affects the structure of HDL.

Lipid transfer mechanism mediated by CETP upon penetration into HDL

CETP faciliates the transfer of cholesterol oleate (ChOE) from HDL to apoB-100-containing lipoproteins, primarily to low-density lipoproteins [34]. Cholesterol oleate appears to compete with triglicerides for an access to the cholesterol ester transfer protein tunnel. Throughout the molecular dynamic simulation, cholesterol oleate is seen to be searching for a path to the cholesterol ester transfer protein tunnel, and the presence of triglicerides appears to prevent its access. Triglicerides reveal a barrier

(c) Dorovsky D. A., Zagayko A. L., 2016 between the tunnel of CETP and the opening. This barrier formed by an aromatic ring-rich region, wich consists mostly of phenylalanine (Phe) residues. The role of triglicerides in HDL thus may be strategic. At tunnel region with long hydrophobic chains, triglicerides are able to open up this aromatic barrier to give cholesterol oleate an access to the tunnel.

Role of $\mathrm{E}_{2}$ oleate in the CETP-HDL interaction

Estradiol oleate is able to interact with $\Omega 5$ at the $\mathrm{N}$ barrel domain end of CETP molecule. Hydrophobic interaction and $\mathrm{H}$-bond formations are found to rule cholesterol ester transfer protein and estradiol oleate interaction. Close contacts were established between the molecules of estradiol oleate and amino acids of $\Omega 5$ (with the Trps located at the beginning of the interaction). These contribute to the immobilization of cholesterol ester transfer protein on high-density lipoprotein particles, allowing further penetration of HDL by CETP, wich induces the opening formation at the $\mathrm{N}$ barrel domain end of cholesterol ester transfer protein molucule.

The four step mechanism as key to the CETP-HDL interaction

First step is the immobilization of cholesterol ester transfer protein on the high-density lipoprotein particle surface promoted by the interaction with apoA-I, POPC, and the presence of estradiol fatty acyl esters. The number of apoA-I per high-density lipoprotein particle contributes to the interaction of cholesterol ester transfer protein with HDL and accelerates the process of penetration by immobilization of CETP molecule. Second step is the penetration of cholesterol ester transfer protein 
into HDL with subsequent opening formation between the Trp-rich flap $\Omega 5$ and $\Omega 6$ at the $\mathrm{N}$ barrel domain end of cholesterol ester transfer protein. The third step is transfer of cholesterol oleate from high-density lipoprotein particle to the $\mathrm{N}$ barrel domain opening of CETP. The final step is transfer of cholesterol oleate from the opening to the tunnel of cholesterol ester transfer protein through an aromatic ring-rich region, acting as a some sort of barrier and penetrable with the help of triglicerides. It was also suggested that CETP-bound cholesterol oleate may serve to stabilize the cholesterol ester transfer protein tunnel. Cholesterol ester transfer protein tunnel can simultaneously host several lipids, thus CETP-bound cholesterol oleate may be easily exchanged or remain within the tunnel when cholesterol oleate core molecules are passing through.

\section{CETP-deficient cell differentiation status}

It was previously reported that cells wich has cholesterol ester transfer protein deficiency accumulate about half as much triglicerides as control cells, and that lipid droplets in this type of cells are fewer in number and smaller. The reduced trigliceride content of CETP-deficient cells is due to reduced TG biosynthesis [15].

During cellular differentiation into adipocytes, the transcription factors PPAR $\gamma$ and CEBP play key roles in the transcriptional cascade wich leads to the induction of pathways involved in trigliceride storage and synthesis [13]. In human adipocytes, cholesterol ester transfer protein expression is also induced during this process of differentiation $[12,28]$. Cholesterol ester transfer protein expression reaches its maximum point small lipidpoor adipocytes, and then decreases when adipocytes become filled with triglicerides [27, 28]. The highest level of cholesterol ester transfer protein expression can be observed in tissues that store lipids [8].

Cellular TG synthesis and movement

It was previously suggested that intracellular cholesterol ester transfer protein may transport cholesterol esters and triglicerides between cellular membranes. It was also demonstrated that intact CETP-deficient cells have reduced the capacity to transfer newly synthesized triglicerides into lipid droplets [15]. Furthermore, it was observed that microsome-associated trigliceride lipase activity was 2-fold higher in cholesterol ester transfer protein-deficient cells when trigliceride biosynthesis is stimulated.

Elevated cholesterol ester transfer protein (CETP) activity, a major determinant of the atherogenic dyslipidemia, and atherosclerotic cardiovascular disease in South Asians

Cholesterol ester transfer protein activity was elevated by $30 \%$ in South Asians relatively to European Caucasians, even when adjusted for age and sex. This difference in cholesterol ester transfer protein activity between the two population groups is similar in extent to the cholesterol ester transfer protein activity elevation levels demonstrated in humans with the metabolic syndrome dis- playing the atherogenic dyslipoproteinemia when compared with normal healthy controls [10]. Furthermore, cholesterol ester transfer protein activity correlated strongly with all of the major elements of the atherogenic dyslipoproteinemia - high LDL particle number, elevated triglycerides and low HDL-C in both European Caucasians and South Asians $[11,31]$. These findings mean that the difference in cholesterol ester transfer protein activity plays a key role in the differences in the lipoprotein profiles among the populations. Serum triglycerides are a major driver of CETP activity [7, 19] and South Asians are known to have greater fasting serum triglycerides compared to European Caucasians [18]. It was reported that fasting serum triglycerides, VLDL particle number and the triglyceride content of VLDL particles correlated positively with cholesterol ester transfer protein. The regression line of serum triglycerides versus cholesterol ester transfer protein activity was shifted to the left in South Asians relative to European Caucasians, indicating that for a given serum triglyceride level, cholesterol ester transfer protein activity is elevated in South Asians compared with European Caucasians. Therefore, elevated triglycerides only incompletely explain the elevated CETP activity in South Asians compared with European Caucasians. However, we found that cholesterol ester transfer protein activity was positively and strongly correlated with both low-density lipoprotein particle number and apoB and both associations were stronger than between CETP activity and LDL-C. The notion that cholesterol ester transfer protein activity affects low-density lipoproteins metabolism in addition to its well established effects on highdensity lipoprotein metabolism [30] are supported by observations in Japanese individuals with a lack of functional copy of the cholesterol ester transfer protein gene, who exhibit large increases in HDL-C and significant decreases in their LDL-C compared to unaffected individuals [3]. Recent GWAS findings that single nucleotide polymorphisms in cholesterol ester transfer protein associate significantly with both HDL-C and LDL-C provide additional support for this concept $[16,35]$. In our analysis of CETP activity with clinical ASCVD, we found that CETP activity did not correlate significantly with carotid IMT values in either ethnic group.

Anacetrapib reduces LDL-C by inhibition of CETP activity and reduction of plasma PCSK9

Inhibition of CETP lowers plasma LDL-C concentration HDL-C, suggesting it might prevent development of cardiovascular diseases. Anacetrapib decreased gene expression of cholesterol biosynthesis pathways, most probably through inhibition of Srebp-1 and / or Srebp-2 signaling. Anacetrapib also increased cholesterol clearance by the liver, without affecting VLDL-trigliceride production, as well as decreased plasma PCSK9 level. These results may indicate that cholesterol ester transfer protein inhibition results in modified particles wich more susceptible for hepatic clearance. Thus, anacetrapib reduces very-low-density lipoproteins by two mechanisms. This 
reduction of very-low-density lipoproteins is the focal point in creating the atheroprotective effects of anacetrapib [17].

The observed reduction in PCSK9 levels in plasma serum after such treatment is in accordance with findings in rhesus macaques [36]. Accumulating evidence shows that PCSK9 inhibition is a beneficial strategy of reducing cholesterol-enriched LDL both in clinical and preclinical studies [25, 32]. This effect can be explained by increase of low-density lipoproteins clearance as a result of reduction of the hepatic low-density lipoprotein receptor degradation. The main activity of cholesterol ester transfer protein is to transfer CE from high-density lipoproteins to very-low-density lipoproteins in exchange for triglicerides. This lipoprotein remodeling activity of cholesterol ester transfer protein renders very-low-density lipoproteins less susceptible for clearance. In mice, anacetrapib treatment results in an increased plasma apoE levels, which is an indicator for lipoprotein remodeling. Functional apoE-LDLr pathway is a milestone pathway in the clearance of remnants from plasma and, subsequently, in the atherosclerosis development [1]. Anacetrapib treatment in humans also shown an increased plasma level of apoE [4].

However, the increased catabolism of very-low-density lipoprotein particles and thus antiatherogenic properties were clearly not sufficient to offset or overrule the adverse side effects of anacetrapib [20,21].

Effect of CETP mutations on lipid transfer between various lipoproteins

Qiu et al. [26] described multiple human cholesterol ester transfer protein mutants that have altered ability to transfer triglicerides and cholesterol esters. For example, the Q199A CETP mutant strongly prefers triglicerides as a substrate, much like that observed for hamster cholesterol ester transfer protein [22]. These mutations modify the internal hydrophobic lipid transfer tunnel of CETP without marked alteration of lipoprotein binding [26]. We observed that human cholesterol ester transfer protein with an amino acid mutation had markedly higher triglyceride / cholesterol ester substrate preference than the wild-type cholesterol ester transfer protein. It was also found that the human cholesterol ester transfer protein mutants with higher preference for cholesterol esters versus triglicerides than wild-type cholesterol ester transfer protein also promoted nonreciprocal lipid transfer, but this occurred for cholesterol esters instead of triglicerides and this lipid movement had an opposite direction (from HDL into VLDL).

Previous studies have shown that CETP binds triglicerides or cholesterol esters contained within the lipoprotein phospholipid surface [23]. The prevailing mechanism for CETP-mediated lipid transfer is through the carrier mechanism, where cholesterol ester transfer protein containing lipid cargo binds to a lipoprotein, releases this lipid, and then picks up another lipid wich is prior to dissociating $[2,26,33]$. By this mechanism cholesterol ester transfer protein facilitates either exchange of different lipids (heteroexchange) or the the exchange of like lipid molecules (homoexchange). Cholesterol ester transfer protein is also capable of delivering cholesterol esters or triglicerides to an acceptor particle and leaving the particle surface without picking-up any CE or TG, thus mediating a one way transfer $[22,24]$. We propose that nonreciprocal lipid transfer is amplified when cholesterol ester transfer protein mutants with altered preference for triglicerides versus cholesterol esters interact with lipoprotein substrates with widely differing amounts of triglicerides or cholesterol esters. Thus, when Q199A CETP with a markedly elevated preference for triglicerides as a substrate, binds triglicerides in the very-low-density lipoproteins then dissociates from them and binds to a HDL, it encounters extremely low amounts of its preferred substrate because of the low triglicerides content of highdensity lipoproteins. As a result, the chance that cholesterol ester transfer protein will deliver its triglicerides then dissociate from high-density lipoprotein particle before binding any other lipid is enhanced. The converse process occurs when the cholesterol ester transfer protein's substrate preference is altered for a great prefer cholesterol esters over triglicerides. In this model, the limiting events occur on very-low-density lipoproteins due to its low cholesterol esters content, leading to an enhanced probability that cholesterol ester transfer protein will deliver CE to VLDL and dissociate without binding any lipid in very-low-density lipoproteins.

Humans with genetical deficiency in CETP have multiple lipoprotein abnormalities, including marked hyperalphalipoproteinemia [5]. Because cholesterol ester transfer protein deficiency increases HDL level in plasma, there has been a lot of interest in developing it's pharmacologic inhibitors. Thus far, cholesterol ester transfer protein inhibitors studied in clinical trials equally inhibit the CETP-mediated transfer of both triglicerides and cholesterol esters.

There is data that suggests the possibility to modify the lipid transfer properties of cholesterol ester transfer protein by altering its preference for cholesterol esters versus triglicerides as a substrate [29]. With this being said, and given the capacity of cholesterol ester transfer protein to modify and alter lipoprotein metabolism, a novel pharmacologic strategy was proposed where drugs are designed to modify the lipid substrate preference of cholesterol ester transfer protein instead of simply blocking its activity. This approach provides an opportunity to improve the lipid transfer properties of cholesterol ester transfer protein and to harness its capacity to alter lipid metabolism to achieve specific beneficial outcomes.

\section{REFERENCES}

1. Ason B. PCSK9 inhibition fails to alter hepatic LDLR, circulating cholesterol, and atherosclerosis in the absence of ApoE / B. Ason, J. W. van der Hoorn, J. Chan // J. Lipid Res. - 2014. - Vol. 55. - P. 2370-2379. 
2. Barter P. J. Kinetic studies of the transfer of esterified cholesterol between human plasma low and high density lipoproteins / P. J. Barter, M. E. Jones // J. Lipid Res. - 1980. - Vol. 21. - P. 238-249.

3. Barter P. J. Targeting cholesteryl ester transfer protein for the prevention and management of cardiovascular disease / P. J. Barter, J. J. Kastelein // J. Am. Coll. Cardiol. - 2006. - Vol. 47. - P. 492-499.

4. Bloomfield D. Efficacy and safety of the cholesterol ester transfer protein inhibitor anacetrapib as monotherapy and coadministered with atorvastatin in dyslipidemic patients / D. Bloomfield, G. L. Carlson, A. Sapre // Am. Heart J. - 2009. - Vol.157. - P. 352-360.

5. Brown M. L. Molecular basis of lipid transfer protein deficiency in a family with increased high-density lipoproteins / M. L. Brown, A. Inazu, C. B. Hesler // Nature. - 1989. - Vol. 342. - P. 448-451.

6. Bruce C. Molecular determinants of plasma cholesterol ester transfer protein binding to high density lipoproteins / C. Bruce, W. S. Davidson, P. Kussie // J. Biol. Chem. - 1995. - Vol. 270. - P. 11532-11542.

7. Cuchel M. Is the cholesteryl ester transfer protein proatherogenic or antiatherogenic in humans? / M. Cuchel, D. J. Rader // J. Am. Coll. Cardiol. - 2007. Vol. 50. - P. 1956-1957.

8. Drayna D. Cloning and sequencing of human cholesterol ester transfer protein cDNA / D. Drayna, A. S. Jarnagin, J. McLean // Nature. - 1987. - Vol. 327. P. 632-634.

9. Duffy D. Update on strategies to increase HDL quantity and function / D. Duffy, D. J. Rader // Nat. Rev. Cardiol. - 2009. - Vol. 6. - P. 455-463.

10. Dullaart R. P. Plasma cholesteryl ester transfer, but not cholesterol esterification, is related to lipoprotein-associated phospholipase A2: Possible contribution to an atherogenic lipoprotein profile / [R. P. Dullaart, A. Constantinides, F. G. Perton et al.] // J. Clin. Endocrinol. Metab. - 2011. - Vol. 96. - P. 1077-1084.

11. Ebenbichler C. F. Relationship between cholesteryl ester transfer protein and atherogenic lipoprotein profile in morbidly obese women / [C. F. Ebenbichler, M. Laimer, S. Kaser et al.] // Arterioscler Thromb. Vasc. Biol. - 2002. - Vol. 22. - P. 1465-1469.

12. Gauthier B. Cholesterol ester transfer protein gene expression during differentiation of human preadipocytes to adipocytes in primary culture / B. Gauthier, M. Robb, R. McPherson // Atherosclerosis. - 1999. Vol. 142. - P. 301-307.

13. Gregoire F. M. Understanding adipocyte differentiation / F. M. Gregoire, C. M. Smas, H. S. Sul // Physiol. Rev. - 1998.- Vol. 78. - P. 783-809.

14. Hayek T. Hypertriglyceridemia and cholesterol ester transfer protein interact to dramatically alter high density lipoprotein levels, particle sizes, and metabolism - studies in transgenic mice / T. Hayek, N. Azrolan, R. B. Verdery // J. Clin. Invest. - 1993. Vol. 92. - P. 1143-1152.
15. Izem L. Possible role for intracellular cholesterol ester transfer protein in adipocyte lipid metabolism and storage / L. Izem, R. E. Morton // J. Biol. Chem. 2007. - Vol. 282. - P. 21856-21865.

16. Keebler M. E. Association of blood lipids with common DNA sequence variants at 19 genetic loci in the multiethnic United States National Health and Nutrition Examination Survey III / [M. E. Keebler, C. L. Sanders, A. Surti et al.] // Circ. Cardiovasc. Genet. 2009. - Vol. 2. - P. 238-243.

17. Kühnast $\mathrm{S}$. Anacetrapib reduces progression of atherosclerosis, mainly by reducing non-HDL-cholesterol, improves lesion stability and adds to the beneficial effects of atorvastatin / S. Kühnast, S. J. van der Tuin, J. W. van der Hoorn // Eur. Heart J. - 2015. Vol. 36. - P. 39-48.

18. Lear S. A. Visceral adipose tissue accumulation differs according to ethnic background: Results of the Multicultural Community Health Assessment Trial (M-CHAT) / [S. A. Lear, K. H. Humphries, S. Kohli et al.] // J. Clin. Nutr. - 2007. - Vol. 86. - P. 353-359.

19. Mann C. J. Mechanism of plasma cholesteryl ester transfer in hypertriglyceridemia / [C. J. Mann, F. T. Yen, A. M. Grant et al.] // J. Clin. Invest. - 1991. - Vol. 88. P. 2059-2066.

20. Millar J. S. Effects of the cholesterol ester transfer protein inhibitor torcetrapib on VLDL apolipoprotein E metabolism / J. S. Millar, M. E. Brousseau, M. R. Diffenderfer // J. Lipid Res. - 2008. - Vol. 49. P. 543-549.

21. Millar J. S. Effects of the cholesterol ester transfer protein inhibitor torcetrapib on apolipoprotein B100 metabolism in humans / J. S. Millar, M. E. Brousseau, M. R. Diffenderfer // Arterioscler. Thromb. Vasc. Biol. 2006. - Vol. 26. - P. 1350-1356.

22. Morton R. E. Cholesterol ester transfer proteins from different species do not have equialent activities / R. E. Morton, L. Izem // J. Lipid Res. - 2014. - Vol. 55. P. 258-265.

23. Morton R. E. Concentration of neutral lipids in the phospholipid surface of substrate particles determines lipid transfer protein activity / R. E. Morton, J. V. Steinbrunner // J. Lipid Res. - 1990. - Vol. 31. P. 1559-1567.

24. Morton R. E. Inter-relationship of lipids transferred by the lipid-transfer protein isolated from human lipoproteindeficient plasma / R. E. Morton, D. B. Zilversmit // J. Biol. Chem. - 1983. - Vol. 258. - P. 11751-11757.

25. Norata G. D. Targeting PCSK9 for hypercholesterolemia / G. D. Norata, G. Tibolla, A. L. Catapano // Annu. Rev. Pharmacol. Toxicol. - 2014. - Vol. 54. - P. 273-293.

26. Qiu X. Crystal structure of cholesterol ester transfer protein reveals a long tunnel and four bound lipid molecules / X. Qiu, A. Mistry, M. Ammirati // Nat. Struct. Mol. Biol. - 2007. - Vol. 14. - P. 106-113.

27. Radeau T. Cholesterol ester transfer protein (CETP) mRNA abundance in human adipose tissue: Rela- 
tionship to cell size and membrane cholesterol content / T. Radeau, P. Lau, M. Robb, M. McDonnell // J. Lipid Res. - 1995. - Vol. 36. - P. 2552-2561.

28. Radeau T. Preferential expression of cholesterol ester transfer protein mRNA by stromal-vascular cells of human adipose tissue / T. Radeau, M. Robb, M. McDonnell // Biochim. Biophys. Acta. - 1998. - Vol. 1392. P. 245-253.

29. Ranalletta M. Biochemical characterization of cholesterol ester transfer protein inhibitors / M. Ranalletta, K. K. Bierilo, Y. Chen // J. Lipid Res. - 2010. - Vol. 51. P. 2739-2752.

30. Rashid S. Mechanisms of HDL lowering in insulin resistant, hypertriglyceridemic states: The combined effect of HDL triglyceride enrichment and elevated hepatic lipase activity / [S. Rashid, T. Watanabe, T. Sakaue et al.] // Clin. Biochem. - 2003. - Vol. 36. - P. 421-429.

31. Stalenhoef A. F. Efficacy and safety of dalcetrapib in type 2 diabetes mellitus and/or metabolic syndrome patients, at high cardiovascular disease risk / [A. F. Stalen- hoef, M. H. Davidson, J. G. Robinson et al.] // Diabetes. Obes. Metab. - 2012. - Vol. 14. - P. 30-39.

32. Stein E. A. Reduction of low-density lipoprotein cholesterol by monoclonal antibody inhibition of PCSK9 / E. A. Stein, F. Raal // Annu. Rev. Med. 2014. - Vol. 65. - P. 417-431.

33. Swenson T. L. Plasma cholesterol ester transfer protein has binding sites for neutral lipids and phospholipids / T. L. Swenson, R. W. Brocia, A. R. Tall // J. Biol. Chem. - 1988. - Vol. 263. - P. 5150-5157.

34. Tall A. R. Plasma cholesterol ester transfer protein / A. R. Tall// J. Lipid Res. - 1993. - Vol. 34. - P. 1255-1274.

35. Talmud P. J. Gene-centric association signals for lipids and apolipoproteins identified via the HumanCVD BeadChip / [P. J. Talmud, F. Drenos, S. Shah et al.] // Am. J. Hum. Genet. - 2009. - Vol. 85. - P. 628-642.

36. Xie D. Effects of anacetrapib on plasma lipids, apolipoproteins and PCSK9 in healthy, lean rhesus macaques / D. Xie, K. Dunn, A. Kulick / / Eur. J. Pharmacol. - 2014. - Vol. 740. - P. 410-416. 


\section{УДК 577.125.8:612.11/.16 (05)}

\section{Д. А. Доровский, А. Л. Загайко}

КРИТИЧЕСКАЯ РОЛЬ БЕЛКА-ПЕРЕНОСЧИКА ЭФИРОВ ХОЛЕСТЕРОЛА В РАЗВИТИИ АТЕРОСКЛЕРОЗА

Белок-переносчик эфиров холестерола (БПЭХ) - белок плазмы крови, который стимулирует транспорт триглицеридов и сложных эфиров холестерола между липопротеинами. Основной функцией белка является сбор триглицеридов из липопротеинов низкой плотности (лПнП) или липопротеинов очень низкой плотности (лПонП) и их обмен на сложные эфиры холестерола, транспортируемые липопротеинами высокой плотности (ЛПВП). Точечные мутации, приводящие к нарушениям функции белка, приводили к развитию атеросклероза. Эти мутации также увеличивали риск развития ишемической болезни сердца у пациентов с гипертриглицеридемией. Существует большое разнообразие методов лечения кардиоваскулярных заболеваний, которые увеличивают уровни холестерол-содержащих ЛПВП. Среди них важное место занимает модификация функции БПЭХ. Новая фармакологическая стратегия предполагает разработку препаратов, меняющих предпочтение белка-переносчика к субстрату вместо того, чтобы просто блокировать его деятельность. Этот подход дает возможность улучшить свойства БПЭХ в плане переноса липидов и использования этих свойств для изменения липидного метаболизма в борьбе с кардиоваскулярными заболеваниями.

ключевые слова: БПЭХ; липопротеиды; атеросклероз

\section{УДК 577.125.8:612.11/.16 (05)}

Д. А. Доровський, А. Л. Загайко

КРИТИЧНА РОЛЬ БІЛКА-ПЕРЕНОСНИКА ЕСТЕРІВ ХОЛЕСТЕРОЛУ У РОЗВИТКУ АТЕРОСКЛЕРОЗУ

Білок-переносник естерів холестеролу (БПЕХ) - білок плазми крові, який стимулює транспорт тригліцеридів і естерів холестеролу між ліпопротеїнами. Основною функцією білка $є$ збір тригліцеридів з ліпопротеїнів низької щільності (лПнщ) або ліпопротеїнів дуже низької щільності (ЛПдНщ) і їх обмін на естери холестеролу, що транспортуються ліпопротеїнами високої щільності (ЛПВЩ). Точкові мутації, що призводять до порушень функції білка, призводили до розвитку атеросклерозу. Ці мутації також збільшували ризик розвитку ішемічної хвороби серця у пацієнтів з гіпертригліцеридемією. Існує велика різноманітність методів лікування кардіоваскулярних захворювань, які збільшують рівні холестерол-збагачених ЛПВЩ. Серед них важливе місце посідає модифікація функції БПЕХ. Нова фармакологічна стратегія передбачає розробку препаратів, що змінюють перевагу білка-переносника до субстрату замість того, щоб просто блокувати його діяльність. Цей підхід дає можливість поліпшити властивості БПЕХ у плані перенесення ліпідів і використання цих властивостей для зміни ліпідного метаболізму в боротьбі з кардіоваскулярними захворюваннями.

Ключові слова: БПЕХ; ліпопротеїди; атеросклероз

Адреса для листування:

61002, м. Харків, вул. Куликівська, 12.

Національний фармацевтичний університет
Надійшла до редакції 28.10.2016 р. 